\title{
Contributions of Action Research in Management Practices in the Brazilian Public Universities
}

\author{
Odemir V. Baêta ${ }^{1}{ }^{2}$, Mozar J. Brito ${ }^{1}$, Carla Beatriz M. R. Mucci ${ }^{2}$ \& José R. Pereira ${ }^{1}$ \\ ${ }^{1}$ Programa de doutorado em Administração do Curso de Pós-Graduação do Departamento de Administração e \\ Economia, Federal University of Lavras, Brazil \\ ${ }^{2}$ Federal University of Viçosa, Brazil \\ Correspondence: Odemir V. Baêta, Rua Sargento Dias, 305 - Queluz, Conselheiro Lafaiete, MG, Zipcode: \\ 36400-000, Brazil. Tel: 55-7525-1400. E-mail: odemirbaeta@posgrad.ufla.br
}

Received: February 15, 2015 Accepted: February 25, 2015 Online Published: April 27, 2015

doi:10.5539/par.v4n1p68 URL: http://dx.doi.org/10.5539/par.v4n1p68

This paper is supported by Universidade Federal de Viçosa (UFV). We appreciate the support and encouragement of these scientific research projects.

\begin{abstract}
This paper presents theoretical discussion to the possible contributions of the methodology action research for the exercise of reflection and change process, aiming to identify and approach, management theories and practices in Brazilian public universities with the contribution and the intermediation proactive of High Level Technicians (HLT). The reality of the new government and the reflective potential of HLT with training in the field of applied social sciences, as federal civil servants, the possible use of the methodological approach of action research for management practices in universities. The gap between theory and organizational practices in universities lacks methods for such a dichotomy can be minimized. In this context the HLT can suggest as a new server that will gain increasing your space. Action research has applicability in the organizational routine troubleshooting through the experiences and activities of the HLT own in Brazilian university management. Among his skills, many technical includes the methodological proficiency essential to contribute, since, in the conduct of scientific basis, identifying and solving some practical problems in the daily activities of these universities. This proactivity can contribute significantly to better understanding of the theory and minimizing the distance with organizational practice.
\end{abstract}

Keywords: action research, high level technicians, organizational practice, public university

\section{Introduction}

The distance between the theory of public administration and the practice of university management in Higher Education Federal (HEF) in Brazil is considerable, as stated by the studies developed by Brazilian researchers of university management (Silva O., Melo, Ramos, Amante \& Silva M., 2013). Therefore, highlighting the can to present possibilities and contributions to promote such an approach between theory and practice. It appears that the collective space environment of the Brazilian federal universities is subject to reflection and critical construction of knowledge by the theories and organizational practices. The methodology of action research is presented as a possibility of useful tool for research in the humanities and social sciences. Therefore, we present this work to the applicability of the approach for High Level Technicians (HLT, for this acronym in this work from now) with training in the areas of applied social sciences active in their professional context in the federal public universities in Brazil. The definition for this category and focus of Brazilian HEF was defined by my own experience. We hope that through systematization can be presents some solutions to organizational problems through everyday experiences, the experiences of each HLT.

Usually, in scientific practice, the researchers can use of the method empirically action research after identifying a problem and therefore set an object of study in the real world for solving a problem with a scientific possibility grounded. Likewise, HLT will adopt a rigorous scientific approach through the scientific method in conducting problem-solving during the execution of its activities and in the daily management practices and, together with other administrative staff, address and resolve the problems of organizational praxis of university management 
that emerge in their everyday. Thus, this paper presents theoretical discussion to the possible contributions of the methodology action research for the exercise of reflection and change process, aiming to identify and approach, management theories and practices in Brazilian public universities with the contribution and the intermediation proactive of HLT, presumably, a reality which perhaps is not so different in other higher education institutions around the world.

\section{Methodology}

This theoretical work was conducted based on qualitative approach and its systematization was defined by a literature search of relevant topics to discuss: the context of contemporary public administration, university management and the methodological approach action research. To operationalize the bibliographies we used the myendnoteweb program, a free version of Thomas Reuters available on the internet.

The path taken to treat, select and withdrawing the material by the literature search. This scientific work technique is the basis for any scientific nature of research. The same is designed to address the selection and survey the literature on the subject to be searched in order to put the researcher in contact with the material already written with scientific background on the subject. (Godoi, Bandeira-de-Melo \& Silva, 2012). The literature technique aimed to verify the possible limits and contributions of using methodological approach action research presented by specialists. Meanwhile, it was up to this theoretical discussion verify these same opportunities and contributions in the context of management practices carried out in Brazilian public universities and what implications may arise from this practice. Given the above, the objective is to stimulate debate and the theoretical discussion in the academic, scientific and institutional environment, so that light indirectly also to other discussions and related discussions. From the pragmatic point of view, it is expected the possible practical contributions to the reality of HLT who are working in universities.

\section{Context of Contemporary Public Administration}

Administrative activities in the Brazilian public service environment have always been under some kind of model or paradigm from the 20th century. Andion (2012) presents the contributions of Keinert (1994) that classifies paradigms present in Brazilian public administration from 1930 to 1980 and after 1990. The first is influenced by classical administration and a mechanistic view of government action; the second, for an approach to political science; and the last, presents a new paradigm, the socio-centric, the public and public interest. However, Andion (2012) recognizes such contributions and deepens the discussion on the epistemological level in their central assumption, the functional predominance still very present in Brazilian public administration. Therefore, the author advocates dialogue of different theoretical approaches, methods and practices to provide enrichment in this field. Even the government presenting a multidisciplinary field, still dominates a rational and instrumental orientation to maximize efficiency and effectiveness. Thereby, in this context still predominantly prescriptive and functional than the graduate in public administration may be presented as a preparation agent to promote significant changes in administrative procedures.

According to Andion (2012) there is a current model of the New Public Service (NPS) which is a new management model that is based on democratic and citizenship theories with emphasis on the construction of the public interest in addition to the set of individual interests beyond organizational humanism and the theory of discourse, giving importance to dialogue and mediation between different agents who work in public organizations. This possibility is real in Brazilian public administration as shown by the studies and recent research (Baêta, Pereira \& Mucci, 2015). According to the author, in Brazil, the influence of NPS ideas is very recent and occurs mostly after the democratic consolidation from the second half of the 1990. All of these factors have revealed that in the last two decades, Brazil has been consolidating step to step their commitment to the democratic system, creating a favorable climate for new political, institutional and organizational arrangements. In this new dynamic, the author identifies that there is an expansion of studies aimed at understanding the progress and limits of these new institutional arrangements (Paula Paes, 2005). From the perspective of a new organizational reality in Brazilian public administration, professional public administration, can be inserted to meet their social and political role as a mediator and dialogue promoter in conflict resolution and in the changes in the organizational field.

\subsection{New Public Service}

The new public service is an alternative to the old government and new public management that is based on promoting the dignity and the value of the new public service and reaffirm the values of democracy, citizenship and the public interest as prominent figures of public administration. Therefore, this alternative is based on some key principles: to serve citizens; pursue the public interest; give more value to citizenship and public space; think strategically, act democratically (Kettl, 2002). 
Head (2010) confirms that the government manage complex issues and suggests a new thought to effect improvements in the area through recent conceptual and empirical research, contextualizing the challenges and difficulties faced by managers to achieve success in their practices in the long term. This reality consistent with the multifunctional training of social science professionals applied which is prepared to join the work team for solving the problems, regardless of their complexity.

Thus as in the private sector, public sector managers face pressure for results in a diverse environment and constantly changing. Given this situation, many countries have adopted market-based management tools. Managers are constantly forced to reinvent their approaches and their relationships with stakeholders within and outside the public sector (Osborner \& Gaebler, 1994). However, the reality of public administration is characterized by complexity, uncertainty and information overload, multiplicity of objectives. The challenge is to identify carefully the true nature of the complexity of organizational practices problems in Brazilian public universities and determine management arrangements that are more appropriate. However, the technical and rational approach have been criticized for solving complex issues in public institutions. Therefore, these criticisms stem mainly of complex programs that establish objectives and goals are not always achieved.

According to Head (2010) reinforces the need to consider the experiences and perspectives of individuals in organizations and stakeholders in the interventions and the problems that they are affected. Considering the training of professionals in the social sciences to applied areas that operate in Brazilian HEF, plus access to the continuous flow of information, this public servant may be present to make a difference, given its ability to reflection and intervention.

Therefore, modern society is very pluralistic, no longer tolerates more designed and imposed solutions only by specialists in certain processes. The different present and active social subjects in the university in Brazil have important differences in attitudes and values that influence the possibilities of more clear, objective and humane solutions. Thereby modern problems are not always mathematical, descriptive and verifiable. Instead, they are often poorly defined, unstable, has multiple and continuous evolution causality. The HLT who work in Brazilian HEF already witness a world rapidly changing in that there are few certainties and many challenges. Thereby, the classical model of hierarchical bureaucracy should be combined with other multiparadigmatics forms of management that may be more dynamic to facilitate effective adaptation to meet these new challenges urgent and constant scene changes.

Head (2010) supports the idea of expanding the basis for discussion of stakeholders through dialogue and collaboration. The cooperation, coordinated responses and collaborative can be beneficial because knowledge sharing and common development goals are often crucial ingredients to find viable solutions and producing lasting and effective action. However, this requires a lot of mobilization, as well as multifunctional civil servants who can take this approach to be identified with education, persuasion and minimizing conflicts through dialogue. Thus, durable solutions depend on major changes in attitudes and behavior. Therefore, broad participation of all stakeholders is crucial to ensuring a number of contributions to the problem of the frame as well as for its resolution. Likewise, in the most intense forms this involvement can strive to reduce conflict and build the consensus. It is in this sense that the government is adopting increasingly, participatory approaches when administrative and technical solutions traditional management are no longer sufficient. It is precisely at this time that the interdisciplinary approach of HLT and his ability to lead staff and minimize conflicts present with a difference in Brazilian public universities. Despite, collaboration is not always the standard solution for the resolution of complexity and uncertainty, however, should be placed to examine the underlying assumptions of how problems are identified, prioritized and solved.

\subsection{Participation of All Employees in the Problem Process}

For Motta (2013) the government is always looking for new and relevant knowledge to solve practical problems on the organizational everyday. However, it is with this desire that academia generally incurs offer new solutions that break completely with the past practices. Another issue still evidenced by the author refers to the slowness of the administration to the necessary adjustments, common in the private sector, in the face of constant market changes. What can be seen in the author's exhibition is that changes are necessary and urgent. It is in this way, we believe that HLT as one of the administrative staff of HEF servers with a leading role in this matter, for its strategic position in the pro-rectories, superintendents or institutional boards and their proactivity and can therefore stand as an agent that may be the mediator of the changes necessary to speed and avoid procrastination processes and procedures in the institutional context. The administrative technician has much to cooperate in solving administrative problems, because the conduct of the Brazilian federal public universities are run by professors that this function has not yours main activity, because your goal in university is the teaching, research 
and extension (Baêta, Brito \& Souza, 2014). For Abrucio (2007) suggests that the efficient and effective public administration emerges as result of charging and control. In this dimension, it is the HLT a fitting posture their academic and social education and develop their activities and reflectively critical for them to be performed efficiently and achieving the required efficiency.

All these possible changes comes against the recommendation of Denhardt (2012) for a new public service, which is based on the provision of services and troubleshooting. It should be noted again that the resolutions necessary in the implementation of management practices are part of the desired profile of HLT in Brazilian HEF. In this perspective Kettl (2002) states that the government should build new bridges and new possibilities of management and need to develop the ability to flexibly transform and adapt to new realities. Meanwhile, for innovative management practices can be part of the new reality in Brazilian public universities are required HLT involved, skilled, engaged and willing to undertake proactively changes in organizational processes.

\section{Methodological Approach of Action Research}

\subsection{Historical Period and Application of the Methodology}

The approach of action research was developed at two different times ago. In the first phase, until the mid-twentieth century, many researchers believed that Kurt Lewin published in 1946 the first scientific work using action research (Carr, 2006). In the second time, in 1970, action research gained application in education in England, with improvements in their interpretative character and emphasizing the eyes of participants and social actors. However, Thiollent (2007) makes an important observation, we point out that to qualify a search and consider her action research, it is essential that those involved in the problem under observation can act to implement the action.

From the 1970s, science experienced progressive growth of qualitative research by social science methods (Bryman, 1989). Unlike quantitative research, qualitative enables the researcher to understand phenomena through observation, interpretation and description. Among the possibilities highlighted the qualitative approach, De Sordi (2010) considers the emerging action research as an under-applied methodology in the organizational environment. However, its use requires prior knowledge and scientific nature of care so that your application is not thereby confused with other strategies or as an extension of the case study, or even continue to be labeled as a driving story in the mold a consulting project. However, the HLT for its academic and scientific training can make use of its methodological knowledge and further contribute to maximize the applicability of technical and investigative approaches to solving problems in your workplace, with a more scientific and professional focus. Note that the work must be performed with the scientific systematization which gives it the necessary degree of scientific. Otherwise, questions like these could only corroborate the perspective of critical action research pointing to non-scientific method for precisely resemble the consulting projects.

According to Arieli, Friedman and Agbaria (2009), action research is based on the conviction of participation and become aware of their potential, increasing their problem-solving ability, becoming self sufficient and less dependent. The author further states that the moments of reflection in the construction of the methodology can be useful if the administrative technical servers present interest in participating in the research process. It is therefore to HLT a unique and original opportunity to motivate and stimulate the direct involvement of everyone in the process. However, it is necessary to have participation of fact, if those involved do not participate, it creates a "pseudo participation" and the inquiry is going nowhere and is determined not a solution.

Among some possibilities and theoretical models of application of action research. The authors Maurer and Githens (2012) present a proposal for a theoretical reframing for action research practices. They consider that there are three categories of action research; a conventional, a review and a dialogical. Explanation of this discussion is a philosophical basis, researchers exemplify these categories, and studies and conceptual foundations in changing literature and organizational development. Therefore, action research has been used as a method to diagnose and solve organizational problems, and when it is not used alone, has been integrated into mixed methods, through process analysis, participatory diagnosis, planning, implementation and evaluation of the intervention. Thus, there is no doubt that these models provide useful frameworks for organizational practice. Likewise to solve the problems, the potential of the categories presented is in creating mutual understanding and learning through dialogue, reflection, critique and action.

\subsection{Dialogic Action Research Model}

One of the action research perspective, the dialogue is emerging. It is the psychological combination of past someone, present and future, that determine the behavior of people at any given time. Thus, the approach of dialogic action research much can assist the public servant in the best behavioral understanding of other servers 
and groups to provide constant interaction and feedback between the parties and thus enable improvements in interpersonal relationships and processes and organizational practices in the HEF.

If many employees participate, better will be participation in the process. Therefore, encourage and motivate the team in research is crucial. These are initial conditions to formulate action strategies and verify the short, medium and long term consequences. Consequently, in the process of formulating strategies for action, it is up to HLT defend the process of action research, socialize knowledge of a particular process and engage in the search for support of the group in question.

Thereby, this is the question also considered crucial, make it clear to all employees involved that theoretical knowledge prior to immediate action, since they are accustomed to the exercise of constant practice. Acting in a way that meets the aspirations of all without direct conflicts and always emphasizing the cordial relations (Arielli et al., 2009).

Thus, the design for action research by Maurer and Githens (2012), have different emphases in the methodological process and route. The first has a traditional orientation when seeking to study problems from the perspective of HLT proficient only methodologically, considering it as the only one to produce knowledge about the investigated object, making it impossible to others involved in the action are gathered together as co-producers of the knowledge generated. Unlike the thought of these authors, the emphasis of action research is the dialogue whose proposition the involvement of all administrative technical servers in action in such a way that provides the critical engagement of civil servants of the Brazilian HEF, when you consider the problems that emerge from the organizational dynamics and their own relationships between those involved. Therefore, is considered in this way, all kinds of subjectivity, are the beliefs, values, tacit knowledge and theoretical models, each with their level of importance in the research process itself, that is, everything is taken into account. In this sense, the theoretical proposal of dialogic action research provides a better understanding and benefits to organizational realities, it contemplates all the possibilities for interaction between those involved, considering the dynamics of own institutional environment and the reflective communication process. This methodological guidance values all objective and subjective aspects of those involved in the work process of HLT in public universities.

\subsection{Some Differences and Convergences of the Dialog Model}

Despite some differences, you can see a convergence in the positions and theoretical models of Tripp (2005) and Maurer and Githens (2012). However, the great advantage of the proposal is the use of dialog model and not just empowerment in decision making of daily actions. Thus, the HLT can check the possibilities to change the interaction process and all involved dialogue. Therefore, in the dialogical research tradition, social research is redefined as a dialogic and reflective process of democratic discussion and a philosophical critique, which is not only concerned with the generation of knowledge about the problem. Instead, it focuses on practical knowledge of farming, which seeks to understand both the interior and cultures and can be obtained by the introduction of dialogue.

According to Smith, Brantini, Chambers, Jensen and Romero (2010) the use of action research also with possibilities of change as they consider the challenges of sharing decision-making power for the unpredictable twists and turns that characterize the action research, a process that Herr and Anderson (2005, p. 69) call "design the airplane during flight," presents itself as an unusual experience for those who are used to plan and manage all aspects of their work. Action research depends on establishing an environment of trust. According to Smith, et al., (2010) also emphasize that the proposal of participatory action research as a possibility of action in the process of producing and spreading knowledge, and enable a better engagement in the organizational context in which it gives the research process and an appreciation of the empirical. Thereby, the possibility of the research process challenge allows the institutional environment of Brazilian HEF is learning between HLT, the average level of administrative staff and other civil servants involved in the particular case of solving a problem in the university. This collaborative process enables also the democratization in the production of knowledge of reality through the process of interaction between the various actors present in the object of analysis scenario. Likewise, as is recommended with the participation of all other realities, such as the public sphere, as appoint research and discussion in public governance work. (Baêta et al., 2015).

Thereby, it is this reality that Carroll, A. Jenkins, Woodward, Kop and E. Jenkins (2011) introduced the use of action research as a reflective practice for the workplace. Relationships and dialogues of HLT with scientific knowledge and public servants without training in the field can be productive and constructive, based on democratic values that encourage diversity, participation and honesty in a world characterized by complexity, uncertainty and change. The action research approach offers the opportunity to reflect critically and discuss the 
ideas of other servers of HEF. Thus, the HLT, the university administrators and even federal civil servants from other institutions, can understand how powerful and effective collaborative work and its relation to aspects of reflection, dialogue, change and feedback.

Thus, Levin (2012) further strengthens a major issue - the rigor in research. If the research generates useful knowledge that can have a practical application, is a plus, but is not considered mandatory for a good action research. Therefore, we ask: how can the current HLT who work in Brazilian HEF through action research contribute to the theory and practice of management in public universities? We believe that from the essence of the research is possible to produce new knowledge by applying scientifically accepted methods. Actions during the research process must comply with relevant practices, norms and values, contributing to the overall knowledge. Finally, the discussion and data must be analyzed in order to defend the new scientific knowledge.

\subsection{Uses and Possibilities Methodology}

Likewise, another author who presents action research as a possibility to solve practical problems and conflicting situations is Rai (2012). According to the author, action research should be based on the work of Brazilian educator Paulo Freire that defines the driving training, considering all of reality in all its complexity and trying to present creative solutions. Therefore, it is importantly, all action research is participatory type, the need of the servers involved in the problems is always essential. Despite, it is important to stress that not everything that is called participatory research is action research. The approach here drawn is considered a methodology of social research in which there is a broad and explicit interaction between who leads the research - HLT - and the other servers involved in the situation investigated. There is a dual perspective of action and reflection on the development of action research methodology that differs from other conventional methods and practices of the social sciences.

According to Thiollent (2007), main Brazilian author to discuss this approach, action research can be defined as a technical goal, seeking to contribute to the best possible resolution of the problem considered central in investigating, identifying solutions and proposed solutions to convergent actions to assist responsible for research in its transformative process of the situation; and a scientific goal that has the task of information difficult to access by other means, so that it can increase the knowledge base in certain situations.

The authors Coghlan and Brannick (2008) believe that action research is a more appropriate methodology when the research question relates to describe the unfolding of a series of actions over time to a particular group, community or organization; to explain how and why the action of a group of individuals can change or improve the work of some aspects of the system; and also to understand the process of change or improvement and learn from it.

For Tripp (2005) action research enables this enterprise, such investigative process uses a search technique together through the action and contributing to improvements in organizational practices. Therefore, action research can enable continuous innovation, strategic proactive, participatory and interventionist. Thus, the public server HLT trained in courses of applied social sciences areas show that it is possible to link theory to practice in a continuous growth relationship, recognition and visibility of their work. The possibility of using this methodology is due to the flexibility, a strong interaction between civil servants who work in Brazilian HEF in their fields and the possibility of participation of other subjects in research. Moreover, the defined practical problems can be subjective phenomena and full of knowledge, experiences, myths, taboos and prejudices that certainly emerge more easily in group expressions. Therefore, it is identified in action research a dialogical critical and reflexive action allowing to voice, time and opportunity for expression to these subjects in the construction of organizational practices in Brazilian federal universities.

\section{Discussions}

The term research refers to the production of knowledge and the term action, the intentional modification of a given reality. In this way, action research is the production of knowledge guided by practice, with the modification of a given reality occurring as part of the research process. In this research method, and why not work, knowledge is produced and the reality is modified simultaneously, each occurring due to the other. The configuration of the action research depends on your goals and the context in which it is implemented.

If the HLT has an interest in the use of methodological approach action research to prepare or update scientifically through an updated theoretical framework on a particular theme related to its activities in the HEF. After this preview is necessary to identify gaps and seek the problems that need resolution (Avison, Baskerville \& Myers, 2001). Likewise, following this same orientation as the theoretical basis, it is necessary that the HLT set a theory that allows it a critical view of the existing problem that can somehow be significant and important 
to socialize with other administrative technical servers in your university, your unit administrative and technical development work. Consequently, the identification of theoretical problems will enable the public server the first confrontation with the reality that you will be familiar and easily accessible. It is rare to see that it is not possible to establish a confrontation of a problem in the implementation of activities in Brazilian HEF as a scientific problem in the workplace capable of effective resolution. Often, these solutions help improve organizational praxis and the knowledge base in the area in question.

The definition of the theoretical framework is a critical view of the research process than has been produced to date and will be of great importance for the development and application of the methodology. The quest is to build the theoretical framework as visual basic research previously developed by other researchers. This framework helps identify and organizing concepts from research of relevance, which can be characterized as state of the art. It is known that the HLT of HEF not find problems to acess and use of action research and the use of different techniques needed to be employed in the collection and generation of data in your workplace. Since in their daily activities in carrying out their professional activities there is a certain autonomy in the conduct of these tasks, the constant systematization, the search process information for decision-making, which in fact qualify for skillfully combine the use of different techniques collection and generation of data which only further strengthen this stage of the research, its validity. According to Woodside and Wilson (2003), the possibility of using different research techniques in action research corroborates its scientific rigor. Among the most common techniques are participant observation - what to HLT is easy to apply to be entered in their own work environment and consequently a new and possible research environment.

According to Cooke (2006), action research can assist in administrative procedures and in the construction of knowledge and must have committed the appreciation of the relationship and mutual understanding between who leads the process and the other servers, as well as interventions in reality but, according to the author, does not always happen that way, since that action research, in some cases, does not advance in proposing changes that truly necessary.

The main challenge of action research is to promote investigations that have as proposals break with the dichotomy between knowledge and practice, changing the organizational reality by the construction process itself of this same reality. This methodological approach has much to contribute in the construction of organizational practices of university management in the Brazilian federal public universities, and not least, allows the questioning of the practice. The advantage is the HLT make your own workplace, your local research, too. Thus, corroborates the best approximation between theory and practice, once so far in the current reality of Brazilian public university management. In addition, to turn your professional field in its own object of study for the continuous improvement of organizational processes. It should be noted, that in this way, the HLT in their professional practice will also definitely contributing to the construction and spread of knowledge with a reflective and critical, and why not say pragmatic, to solve their own problems with the professionalism that you should be peculiar, added to all this, the scientific rigor.

Moreover, action research has more to offer not only in bringing the theory and practice, but enable the academic and scientific circles go beyond the walls of universities and research centers and close to reality, and pragmatically, the sectors of federal public universities to not only objects and subjects of organizational research, but intermediaries in the co-production of knowledge in the university management.

This is a methodological alternative that presents itself as a chance for the distance between theory and practice of management in universities can be minimized by a multi-professional, reflective, critical and systematic - the social sciences area HLT applied. It being possible for these public servants with critical training can help Brazilian university management in the process of reflection of their organizational practices be changed, these practices, many times, functional and rational. It is a fact that the government is constantly looking for new approaches to the solution of practical problems of everyday life. Therefore, action research, especially the dialogue has proven to be a research strategy that may be useful in the performance of HLT Brazilian HEF in order to produce knowledge and solve practical problems.

\section{Conclusions and Recommendations}

Despite, frequently practices of several researchers who use certain environments of Brazilian IFES as empirical drives to their studies and research, not always provide for these same units that part or all of the knowledge, the result of their work. Therefore, noting that the HLT to make use of action research as a methodological approach will be presented in a professional and social duty, namely, the generation of collaborative knowledge with the administrative technical servers really are closest to the problems. No disciplinary one-dimensional perspective is sufficient to solve practical problems. Thus, action research as a possibility of solution should be 
multidisciplinary and have as their own partners involved in the problem. Create knowledge results in action, but also aims to train the administrative staff servers through the process of building and using your own knowledge.

Thereby, action research, among the various methodological approaches that can be used by HLT Brazilian HEF, stands out for objectifying the transformation of an organizational reality through a planned action; to insert themselves HLT in the field collection and data generation, encouraging interaction between each other colleagues administrative technical servers; the collaboration of the participants as agents of transformation in your reality, able to modify their management practices through continuous learning process.

Thus it is recommended that the HLT beyond their professional practice to develop and improve constantly their knowledge and methodological practice and disseminate knowledge also within the Brazilian HEF, thus demonstrating, once technical and behavioral competence. This is not a fad, but a new reality that only enrich the work of HLT and innovate the area of Brazilian university management, to conduct its work processes with professionalism, ethics, competence and why not engagement and scientific rigor in promoting organizational changes in this new context of the Brazilian public service.

However, even though it may seem at first analysis of this theoretical discussion, it is important to emphasize that the action research methodology is not a miracle solution to solve all the problems with management practices in everyday life of Brazilian public university organizations. Therefore, the main objective is to present as a possibility to contribute in management practices in an inclusive and participatory context, a reality of Brazilian federal public university.

At the end of this work returns to the initial goal, the contribution to launch the debate and reflection of these questions with scientific character and exposed to academics, professors, researchers and practitioners of university management on the applicability possibilities of epistemological and methodological knowledge in this context. What is sought with this discussion is exposed mainly to the HLT that it is to develop methodological proficiency only to fulfill the rite of passage when he developed the monograph, an academic obligation of bachelor's, once, attended by they over Brazil. But aware of the methodological knowledge and scientific foray present much more than a final academic product or a successful scientific intervention. The more technical and behavioral skills, HLT present, the better your reflective capacity and solving professional problems. To all this, what is suggested is to make the use and applicability of its methodological and scientific knowledge, specifically, action research in a working environment and daily actions in the reality of management practices of Brazilian public universities. Finally, there is development in this field will give you a greater sense of curiosity, with the necessary reflection and critical thinking of a HLT prepared for the new reality of public administration that is present in Brazilian HEF.

Probably the major limitation of this type of methodological action is its application to other types and models of organizations that do not prioritize or do not encourage participation in social and professional issues inherent in its work processes, especially in private organizations. In such enterprises, the facilitator of action research can find limitations to implement the procedure. Therefore, the challenges are many such cases. Even as it is necessary, consider it should be noted that the challenges in using this methodology are the technical and behavioral aspects, the first will be the proper development of methodological criteria that the technique requires as the fulfillment of research protocols, the second the development of leadership skills, listening and easing actions and relations with other professional participants involved.

Thereby, as a suggestion for future research is recommended to case studies on the applicability of the action research scholars, professors and university management researchers in many different university settings, are the most distinctive public, private and community sectors, beyond the contexts space, in different geographical parts of the world. In addition to also pursue other methodological and scientific approaches with practical application possibilities in everyday HLT public universities.

\section{References}

Abrucio, L. F. (2007). Trajetória recente da gestão pública brasileira: um balanço crítico e a renovação da agenda de reformas. Rev. Adm. Pública, Edição Especial Comemorativa, Rio de Janeiro, p. 67-87. http://dx.doi.org/10.1590/S0034-76122007000700005

Andion, C. (2012). Por uma Nova Interpretação das Mudanças de Paradigma na Administração Pública. Cadernos EBAPE. BR-FGV, Rio, 10(1), 1-19. http://dx.doi.org/10.1590/S1679-39512012000100003

Arieli, D., Friedman, V. J., \& Agbaria, K. (2009). The paradox of participation in action. Action Research, 7(3), 263-290. http://dx.doi.org/10.1177/1476750309336718

Avison, D., Baskerville, R., \& Myers, M. (2001). Controlling action research projects. Information Technology \& 
People, 14(1), 28-45. http://dx.doi.org/10.1108/09593840110384762

Baêta, O. V., Brito, J. M., \& Souza, R. B. (2014). Strategy as discursive practice in a Brazilian public university: a look under the perspective of critical discourse analysis. Public Administration Research, 3(2), 17-27. http://dx.doi.org/10.5539/par.v3n2p17

Baêta, O. V., Pereira, J. R., \& Mucci, C. B. M. R. (2015). Contributions of Communicative of Rationality for the Brazilian Public Governance. Business and Management Review (BMR), 4(5), 761-769.

Bryman, A. (1989). Research methods and organization studies (contemporary social research) (1st ed.). London: Routledge. http://dx.doi.org/10.4324/9780203359648

Carr, W. (2006). Philosophy, methodology and action research. Journal of Philosophy of Education, 40(4), 421-435. http://dx.doi.org/10.1111/j.1467-9752.2006.00517.x

Carroll, F., Jenkins, A., Woodward, C., Kop, R., \& Jenkins, E. (2011). Exploring How Social Media Can Enhance the Teaching of Action Research. Action Research, 10(2), 170-188. http://dx.doi.org/10.1177/1476750311424945

Coghlan, D., \& Brannick, T. (2008). Doing action research in your own organization. Action Research. http://dx.doi.org/10.1177/1476750308094649

Cooke, B. (2006). The Cold War origin of action research as managerialist cooptation. Human Relations, 59(5), 665-693. http://dx.doi.org/10.1177/0018726706066176

De Sordi, J. O. (2010). Análise da Estratégia de Pesquisa Declarada como Pesquisa-ação por Pesquisadores Brasileiros da Área de Administração. Revista e Gestão, 6(1), 1-20.

Denhardt, R. B. (2012). Teoria da Administração Pública (6th ed.). São Paulo: Ed. Cen. Learning.

Godoi, C. K., Bandeira-de-Melo, R., \& Silva, A. B. (2012). Pesquisa qualitativa em estudos organizacionais: paradigmas, estratégias e métodos. São Paulo: Editora Saraiva.

Head, B. W. (2010). How Can the Public Sector Resolve Complex Issues? Strategies for Steering, Administering and Coping. Asia-Pacific Journal of Business Administration, 2(1), 8-16. http://dx.doi.org/10.1108/17574321011028954

Herr, K., \& Anderson, G. (2005). The action research dissertation. Thousand Oaks, London: Sage Publications.

Keinert, T. M. M. (1994). Os paradigmas da administração pública no Brasil (1900-1992). Rev. Adm. Pública, 34(3), 41-48.

Kettl, D. F. (2002). The Transformation of Governance: public admistration for twenty-first century. Baltimore: The Johns Hopkins Press.

Levin, M. (2012). Academic integrity in action research: Action Research, 10(2), 133-149, London: Sage Publications. http://dx.doi.org/10.1177/1476750312445034

Lewin, K. (1948). Action research and minority problems. In G. W. Lewin (Ed.), Resolving Social Conflicts. New York: Harper e Row.

Maurer, M., \& Githens, R. P. (2012). Toward a reframing of action research for human resource and organization development - Moving beyond problem solving and toward dialogue. Action Research, 8(3), 267-292. http://dx.doi.org/10.1177/1476750309351361

Motta, P. R. M. (2013). O Estado da Arte da Gestão Pública. São Paulo: REC.

Osborne, D., \& Gaebler, T. (1994). Reiventando o governo: como o espirito empreendedor está transformando o setor público (3rd ed.). Brasília: MH Comunicações.

Paes de Paula, A. P. (2005). Por uma Nova Gestão Pública. Rio de Janeiro: FGV.

Rai, R. K. (2012). A participatory action research training initiative to improve police effectiveness. Action Research, 10(3), 225-243. http://dx.doi.org/10.1177/1476750312439901

Silva, J. E. O., Melo, P. A., Ramos, A. M., \& Silva, F. M. (2013). Contributions of PDI and strategic planning in the management of federal universities. Revista GUAL, Florianópolis. http://dx.doi.org/10.5007/1983-4535.2013v6n3p269

Smith, L., Brantini, L., Chambers, D., Jensen, R. V., \& Romero, L. (2010). Between idealism and reality: meeting the challenges of participatory action research. Action Research, 8(4), 407-425. http://dx.doi.org/10.1177/1476750310366043 
Thiollent, M. (2007). Metodologia da pesquisa-ação. São Paulo: Editora Cortez.

Tripp, D. (2005). Pesquisa-ação: uma introdução metodológica. São Paulo: Educação e Pesquisa.

Woodside, A. G., \& Wilson, E. J. (2003). Case studies research methods for theory building. Journal of Business and Industrial Marketing, 18(6/7), 493-508. http://dx.doi.org/10.1108/08858620310492374

\section{Copyrights}

Copyright for this article is retained by the author(s), with first publication rights granted to the journal.

This is an open-access article distributed under the terms and conditions of the Creative Commons Attribution license (http://creativecommons.org/licenses/by/3.0/). 